\title{
Role and Regulation of Credit Rating Agencies: The European Way
}

\author{
Giusy Cavallaro (Corresponding author) \\ Ph.D., Adjunct Professor of Corporate Finance \\ Department of Law, Economics and Sociology, University "Magna Graecia” of Catanzaro \\ Campus Germaneto, Viale Europa, 88100 Catanzaro, Italy \\ E-mail: cavallaro@unicz.it
}

Annarita Trotta

Ph.D., Full Professor of Banking and Finance

Department of Law, Economics and Sociology, University "Magna Graecia” of Catanzaro

Campus Germaneto, Viale Europa, 88100 Catanzaro, Italy

E-mail: trotta@unicz.it

Received: December 8, 2018 Accepted: February 10, 2019 Published: February 13, 2019

doi:10.5296/ijafr.v9i1.14021 URL: https://doi.org/10.5296/ijafr.v9i1.14021

\begin{abstract}
Credit Rating Agencies (CRAs) play a key role in the financial markets: credit rating provides useful information to investors, and it is also widely used for regulatory purposes. Nevertheless, after the subprime meltdown, CRAs have been strongly criticized for worsening the crisis by overrating structured products. Consequently, regulators are reforming the rating industry, worldwide. Therefore, this article investigates the changes regarding the role and regulation of CRAs, focusing on the European Union. To achieve this investigation, the study explores existing literature and examines the European reforms. The research contributes to the ongoing debate on the innovation in financial regulation, by highlighting the key-characteristics of the European approach to CRAs' regulation and supervision. The results note distinct phases of regulation and highlight that certain gray areas relating to business model, overreliance and civil liability should not be ignored.
\end{abstract}

Keywords: Credit rating agencies, Civil liability, European reform, Regulation, Reputation 


\section{Introduction}

Credit Rating Agencies (CRAs) play an important role in the financial system because they could help to reduce any real or perceived informational opacity and asymmetric information that characterizes financial systems (Darbellay and Partnoy 2012). The business of CRAs is focused on the assessment of sovereign and private sector borrowers (Duff and Einig 2015). Nevertheless, in the aftermath of the 2007-2009 subprime meltdowns, rating agencies were accused of having strong responsibility in worsening the crisis, since they had deliberately been overly lax in rating certain structured credit products (Mathis et al. 2009). Subsequently, CRAs aggravated the turmoil by reacting with rapid downgrades from triple A to junk level once the market collapsed. Moreover, it has been stated that the agencies have overvalued the quality of structured finance products (inflated rating) due to conflicts of interest and low competition in the rating industry (Becker and Milbourn 2011). Despite the criticism reported by several scholars, in recent decades (see, among others: Taupin, 2018), the major CRAs remain central entities in financial markets, both in the USA and the EU (White (2018); this is also because the Basel regulatory capital framework has assigned an important role and regulatory power to CRAs recognized as External Credit Assessment Institutions (ECAI). Consequently, following the events of the financial crisis, regulators are reforming the rating industry worldwide. The Basel Committee on Banking Supervision immediately introduced appropriate corrective actions on the rating sector in Basel 3 to limit the incentives for the use of external ratings (Basel Committee on Banking Supervision 2010). Even the Financial Stability Forum (FSF) proposed a set of principles to reduce reliance on CRAs' ratings by removing the references to credit ratings in laws and regulations and to encourage market operators to make their own credit assessments (Financial Stability Forum 2012). In accordance with the actions undertaken by several international bodies and Authorities, the European Commission (EC) also enacted a set of reforms during the 2009-2013 period. Thus, the recent crisis was an opportunity to revive a question that has long been proposed, in theory and in practice, namely: whether and, if so, how CRAs should be regulated. This question represents one of the most contentious issues of the ongoing debate at the international level. However, there is a lack of a detailed and coherent picture that is able to synthesize the different perspectives of analysis to provide answers to the open questions regarding the need for regulation (Dittrich 2007; Staikouras 2012). Therefore, this article investigates the changes regarding the role and regulation of CRAs in theory and practice, focusing on the European Union. To achieve this exploration, the study explores the existing literature and identifies the key points that are useful for examining the European reforms. The research contributes to the ongoing debate on the financial regulation of the rating industry by highlighting the key characteristics of the European approach to CRAs' regulation and supervision. The results identify distinct phases of regulation and highlight that certain gray areas relating to the business model, overreliance and civil liability should not be ignored. The work is organized into two parts. The first provides a comprehensive review of the literature on CRAs, and based on the main issues identified, we investigate the European path to CRAs' regulation. The second part analyzes and compares the European reforms, comparing it to US regulations. Finally, in the conclusion, we examine the effectiveness of European regulation given the results arising from the literature review, and 
we propose several concluding remarks.

\section{Critical Issues of the CRAs Industry: A Literature Review}

The issues associated with the role played by rating agencies in the financial system have been thoroughly addressed by researchers and academicians. By using the keywords "credit rating agencies" on Google Scholar to identify the typology "open access data", we obtained 19,800 results for the 1980 - January 2019 period (excluding patents and citations). However, while researchers extensively use Google for searching, Google is not limited to refereed, high-impact journals and conference proceedings. Therefore, by using another scientific open database, Social Science Research Network (SSRN), we identified 609 papers. Among these results, we focused on reviewed scientific content, books and proceedings. The literature review allowed us to identify four main strands of inquiry relating to 1) Reputation, 2) Rating problems 3) Regulation, and 4) Liability. We have added, compared to the bipartition (reputation versus regulation) analyzed by Dittrich (2007), two additional lines of investigation. Rating problems, linked to the role played by CRAs (Coffee et al. 2010) in the last financial crisis, and Liability, improved after the adoption of European Regulation n. 462/2013 (De Pascalis 2019 and 2015; Maciariello, 2018).

\subsection{Understanding the Reputational Mechanism}

The reputational mechanism has always been and is a key element of the rating industry. Certain scholars, before the subprime crisis, had been against rating industry regulation, believing that the fear of reputational capital loss could be an adequate incentive to prevent opportunistic phenomena (Husisian 1990). In contrast, the view of the inadequacy of a reputational mechanism is gaining strength, especially after the recent bankruptcies and inflated ratings issue for structured finance products (Hunt 2009). In particular, Partnoy (1999) had long theorized an unusual paradox in the rating industry arguing that rating agencies play a major role in every sector of the fixed income market; however, there is overwhelming evidence that credit ratings are of scant informational value. In addition, it is worth emphasizing that Taupin (2018) notes a paradoxical reaffirmation of the power of CRAs during crisis. The relationship between the reputation of CRAs and the competition among CRAs is often investigated in the literature because of the high start-up costs associated with the establishment and maintenance of reputation. Reputational capital represents a natural barrier to entry in the ratings industry that presents an oligopolistic structure (Deipenbrock and Andenas 2016). Moreover, according to Dittrich (2007), a key question of the reputation mechanism is the possibility for major CRAs to transfer an established reputation to new market segments or rating products. Regarding the entry of new competitors, several scholars argue, instead, that the increasing competition does not necessarily improve the quality of credit ratings, but this could lead to inflated ratings (Becker and Milbourn 2011; Mathis et al. 2009). However, Mariano (2012) claims that a good reputation and a competitive rating industry do not ensure accurate ratings if the quality of private information is low, even in the absence of a conflict of interest. Certainly, as De Vincentiis and Pia (2017) have shown, the events related to the global financial crisis have damaged CRAs' reputations, especially the credibility of the three major agencies: Moody's, Standard \& Poor's and Fitch. 


\subsection{Rating Problems and Proposed Solutions}

In the aftermath of the financial meltdown, there has been renewed interest in the discussion of rating problems. The understanding of which measures can create an efficient rating industry leads to the analysis of the following main issues: a) conflicts of interest; b) quality of ratings and methodologies used; c) over-reliance; and d) sovereign rating process. The first line of investigation is focused on conflicts of interest that may arise from both the issuer-paid business model and advisory and ancillary services provided by CRAs to issuers on how to maintain or improve the quality of debt instruments (see, for example: Cash 2018). CRAs express opinions on the securities of issuers who pay for their ratings. Furthermore, rating agencies obtain additional revenues for consulting services on how to package securities; such activities can exacerbate the conflict of interest if they will then rate the same products (White 2013). The financial crisis has shown two main weaknesses in the rating process: the inadequacy of the rating quality and methodologies used, especially in assessing the credit risk of structured financial products; without a doubt, this has led to the issue of high rating (inflated ratings); the delay in their adaptation to changing market conditions. To correct the problems of conflicts of interest and inflated ratings in cases of collusion among the agencies, Stolper (2009) suggests forms of regulation based on the evaluation of the CRAs' behavior; in such a context, the supervisor authority may revoke the authorization to agencies that recorded the worst performance competitor. Taibleson and Listokin (2010) have proposed a different business model on the basis of which rating agencies are paid by issuers, no longer in cash but with the same debt (parceled) they are assessing. The incentive to provide accurate rating is the lower (future) profits in the case of overrating and the use of call and put options on the same debt rated to avoid cases of underrating. Ponce (2012) incorporates the idea of a "platform-pays model" clearing house that assigns the agency to the issuer based on historical data about the performance of CRAs. Moreover, he suggests that the model is complemented by a system of prudential supervision on the quality of credit ratings to prevent cases of collusion and overrating from occurring. Pagano and Volpin (2010) noted that conflicts of interest are exacerbated when the rating companies offer ancillary services to clients who have purchased ratings; this type of activity produces rating shopping, which consists of the research by issuers of the most favorable rating for their financial products (Skreta and Veldkamp 2009). Obviously, issues become more complicated when conflicts of interest are interlinked with the problems that lead to technical weakness of the risk models. Studies in the literature have also investigated the factors that determine the accuracy of the rating process and the quality of ratings (Mariano 2012). In particular, Xia (2014) analyzed how the information quality of ratings from an issuer-paid rating agency (Standard and Poor's - S\&P's) responds to the entry of CRAs compensated by investors (Egan-Jones Rating Company - EJR's). The author finds that the entrance of EJRs led to a significant improvement in the S\&P's rating informative value; indeed, the issuer's paid agency appears to become more conservative in assigning ratings and to adopt more stringent standards. Thus, the results of this paper offer an interesting policy implication regarding the positive effects of the entrance of CRAs adopting investor-paid business models on rating quality. This result is in contrast with the strand of the literature stating that an increase in competition reduces the rating quality (Becker and Milbourn 2011). Regarding rating methodology, most of the surveys are focused on the 


\section{Ml Macrothink}

International Journal of Accounting and Financial Reporting

ISSN 2162-3082

2019, Vol. 9, No. 1

accuracy and timeliness of ratings and the trade-off between these two factors (Lagner and zu Knyphausen-Aufseß 2012). A portion of the scientific community has long argued that the use of ratings for legislative purposes (regulatory licenses) has contributed to encouraging the overreliance on ratings by market participants (Hill 2004; Partnoy 2009). Consistent with these studies, Darbellay and Partnoy (2012) assert that the removal of credit rating references from regulation will force lawmakers and investors to find alternative measures to evaluate credit risk. The overreliance is often settled by scholars in the context of financial innovation; the development of markets connected with the complexity of financial products requires CRAs to address sophisticated methods of evaluation. Several surveys have highlighted the limitations of models used for the evaluation of complex financial instruments (Deb et al. 2011). By observing basic rating properties, such as timeliness, accuracy and volatility, Cheng and Neamtiu (2009) evidenced that the rating agencies improve the timeliness and accuracy of credit ratings, reducing its volatility, under the pressure of investors' criticism and the introduction of regulatory measures. Furthermore, according to the international literature, the major CRAs occupy a remarkable position in the financial industry due to their assessments of the sovereign debts of States (Arezki et al. 2011; Gartner et al. 2011; Tahmoorespour et al. 2018). In particular, Gartner at al. (2011) analyzed the role of CRAs in the European sovereign debt crisis, focusing the attention on the relationships between sovereign debt ratings and the macroeconomic and structural variable. The authors find that ratings affect credit spreads; therefore, arbitrary sovereign ratings downgrades can trigger processes that may influence the financial market and drive relatively healthy countries towards default. In a report focused on the use of credit rating and CRAs' activities, the EC has emphasized that the contagion effects of sovereign debt rating change in the Euro-zone. This finding is due to: "insufficient objectivity and completeness of the sovereign rating process; inappropriate timing of ratings publication; lack of transparency on the sovereign rating process" (European Commission 2011:4).

\subsection{The Regulatory Intervention in the Rating Industry: Results of Prior Studies}

The subprime crisis has forced a rethinking of the "regulatory intervention" in the European Union (EU), leading to the introduction of specific and binding rules. The implementation of a regulatory framework confirms the willingness of legislators to inaugurate a new era, in contrast to one characterized by self-regulatory measures (Deipenbrock and Andenas 2016; Sy 2009). In his survey, Bergevin (2010) notes that the decrease in the use of credit ratings for regulatory purposes could increase the normal checks and balances provided by investors and increase incentives for CRAs to compete on the quality of their ratings. Many criticisms are also addressed to the EU regulatory initiatives: in this respect, Deipenbrock and Andenas (2016) claim that the current supervisory regime leaves unresolved the fundamental structural problems of the rating sector, such as conflicts of interest and the oligopolistic nature arising from the business model adopted. Even Moosa (2017) argues that the regulatory interventions do not suffice to solve the problems that evolved in the financial crisis, and the solution is to revise the decision to make ratings mandatory and a regulatory requirement. In contrast, for Staikouras (2012), the EU Regulation reforms appear to be a well-balanced instrument because they introduced the essential checks upon CRAs, avoiding excessive regulatory intervention. 
In this context, Alsakka et al. (2015) investigated the effect of the European regulatory regime on the market reactions to credit rating actions. Deipenbrock (2018) analyses the ESMA's regulatory powers and performance in the European sector of CRAs. The empirical analysis highlighted that the new regulation does not yet have a strong and consistent effect on market behavior. In a recent work, Picciau (2018) compares the evolution of the US regulatory framework and law on the liability of rating organizations towards investors with the rules adopted by the EU. The author concludes that, in both systems, while it is easier to establish liability in case of intent, the burden of rules generally place a significant, if not insurmountable, obstacle to damage compensations for investors (p. 339). Summarizing from the literature review, it clearly emerges that the opinions of the scholars on the effectiveness of the legislative measures implemented by European regulators are numerous and occasionally conflicting.

\subsection{Civil Liability Regime and Reputational Mechanism of CRAs: A New Viewpoint}

The civil liability regime of CRAs is an emergent critical concept in Academia and one of the most noteworthy aspects of the European Regulation on the rating agencies. (De Pascalis 2019 and 2015). In particular, the opportunity to define forms of liability for the rating industry has been discussed by scholars over the last decade (Gaillard et al. 2018; Mollers and Niedorf 2014; Partnoy 2009) and by rating agencies during the Consultation for the updating of EU legislation (European Commission 2010). Before the financial crisis, several researchers believed that the function of CRAs is to make high-quality assessments of issuer's creditworthiness and that the value of a rating business derives from the agency's reputation in issuing high-quality ratings. Specifically, poor performance will be deterred by the prospect of the loss of reputation capital, and a liability regime is an adjunct to the reputational mechanism (Dittrich 2007; Husisian 1990). According to these scholars, Hill (2004) is contrary to rigid forms of civil liability because they increase the costs incurred by rating agencies and can have chilling effects on the market. The limits related to the theory of reputational capital that impose an in-depth investigation of the issue of liability emerged especially after the recent crisis. As stated in Ellis et al (2012: 216): "If one accepts the fact that reputational capital does not provide sufficient incentives for accurate ratings the question then becomes whether increased civil liability is the answer". Partnoy (2009) has always expressed his support for greater responsibility of rating agencies, stating that lawmakers should eliminate the effective exemption of CRAs from liability and make rating agencies more accountable by treating them as other gatekeepers (e.g., banks, accountants, and lawyers). In response to the CRAs' failure in predicting the bankruptcies of important companies (e.g., Enron) and then the structured debt defaults in the worldwide financial crisis, in the EU, lawmakers have gradually entered a set of civil liability measures for CRAs. At the same time, it should be remembered that, often in the aftermath of a crisis, we are witnessing a significant flowering of rules and regulations. Certain scholars highlighted that legislative enforcement actions remain insufficient to avoid wrong ratings causing further damage (Mollers and Niedorf 2014; Moosa 2017). To enforce the liability rules, Mollers and Niedorf (2014) propose to introduce a European rating agency to break the market's oligopolistic structure and help jump-start small European agencies and a reversal of the burden of proof in the regime of civil liability. In this regard, De Pascalis (2019 
and 2015) claims that the set of civil liability rules is not believed to protect market operators against CRAs but to protect all the actors involved in a potential litigation context (rating agencies included). Moreover, the researcher considers that further reflections on a liability framework will be possible once case law based on infringements of article 35(a) of Regulation n. 462/2013 is formed at the national level. In contrast, by analyzing the national civil regimes of England and Sweden, Nästegård (2015) asserts that Member State legislation likely makes article 35(a) redundant. Given the abovementioned, an in-depth analysis is necessary to assess the accuracy and robustness of the legislative initiatives.

\section{Main Findings From the Literature Overview: An Interpretative Scheme for Innovation Regulatory}

Academia does not provide a definitive answer to the questions about how the credit rating industry should be regulated but offers policy makers and regulators a number of insights that deserve to be considered. Our overview highlights problems and challenges identified in the existing theories. Figure 1 provides a summary of the critical aspects, divided into four critical areas, that characterize the rating sector and represents a scheme that is useful for assessing the regulatory actions to resolve such problems. Consistent with the studies analyzed, the reputation of CRAs, which is an important intangible asset, appears to limit the market entry of new agencies. Indeed, high costs associated with the establishment and maintenance of reputation, strong economies of scale in the acquisition of information about issuers and regulatory recognition as accredited institutions (e.g., NRSROs or ECAI) are natural barriers to the ratings market (Deipenbrock and Andenas 2016; European Commission 2011; White 2010). However, it should be noted that certain recent studies show how the quality of the rating issued by CRAs increases with the market entry of agencies that adopt the "investor-paid" business model (Xia 2014) or in a context characterized by the high quality of private information (Mariano 2012). Most of the papers included in the second critical area focus on conflicts of interest due to the "issuer-pays" remuneration system, the advisory and consultancy services provided, the problem of incentives to shop-rate (rating shopping) and the publishing of inflated ratings to gain or maintain market share (Pagano and Volpin 2010; Sketa and Vedkamp 2009; White 2013). Consequently, the scientific community has proposed several solutions, such as a change in business model or the use of a clearing house (Mathis et al. 2009; Ponce 2012; Taibleson and Listokin 2010). According to the international literature, the use of ratings as regulatory licenses has generated an overreliance on credit ratings by financial market participants (Partnoy 2009; White 2010). This reliance, for structured finance instruments, has expanded due to the difficulties encountered by investors in evaluating these products (Partnoy 2009). Hence, a large number of scholars agree on the need to remove the use of ratings for regulatory purposes and analyze the alternative measures to assess the credit risk and replace CRAs' ratings (Darbellay and Partnoy 2012). As stated previously, there are also discussions regarding a rating's category that affects the assessment of the creditworthiness of sovereign States. The events that characterized the Euro debt crisis have shown the existence of an alarming spillover effect undermining the stability of financial markets associated with an inappropriate timing on ratings publications (Arezki et al. 2011; Gartner at al. 2011). Consequently, there appears to be an orientation for ad hoc regulation and 


\section{Mll Macrothink}

International Journal of Accounting and Financial Reporting

ISSN 2162-3082

2019, Vol. 9, No. 1

supervision of sovereign debt ratings issued in the Euro area. Ultimately, considering what occurred during the worldwide meltdown and the subsequent sovereign debt crisis, regulators have defined a legal liability for CRA activities because it is now clear that the rating can no longer be considered simply an "opinion" on the credit worthiness of an issuer, State or financial product (Haar 2013). In particular, civil liability is becoming a relevant issue and an expanding research field, in theory and practice. As stated in Wang (2018), "the responsibility of credit rating agencies is defined as expert responsibility, and the restoration, compensation and deterrence of civil liability mechanisms is brought into play, which is of significance in reducing the failure of assignable liability and protecting investors' rights and interests".

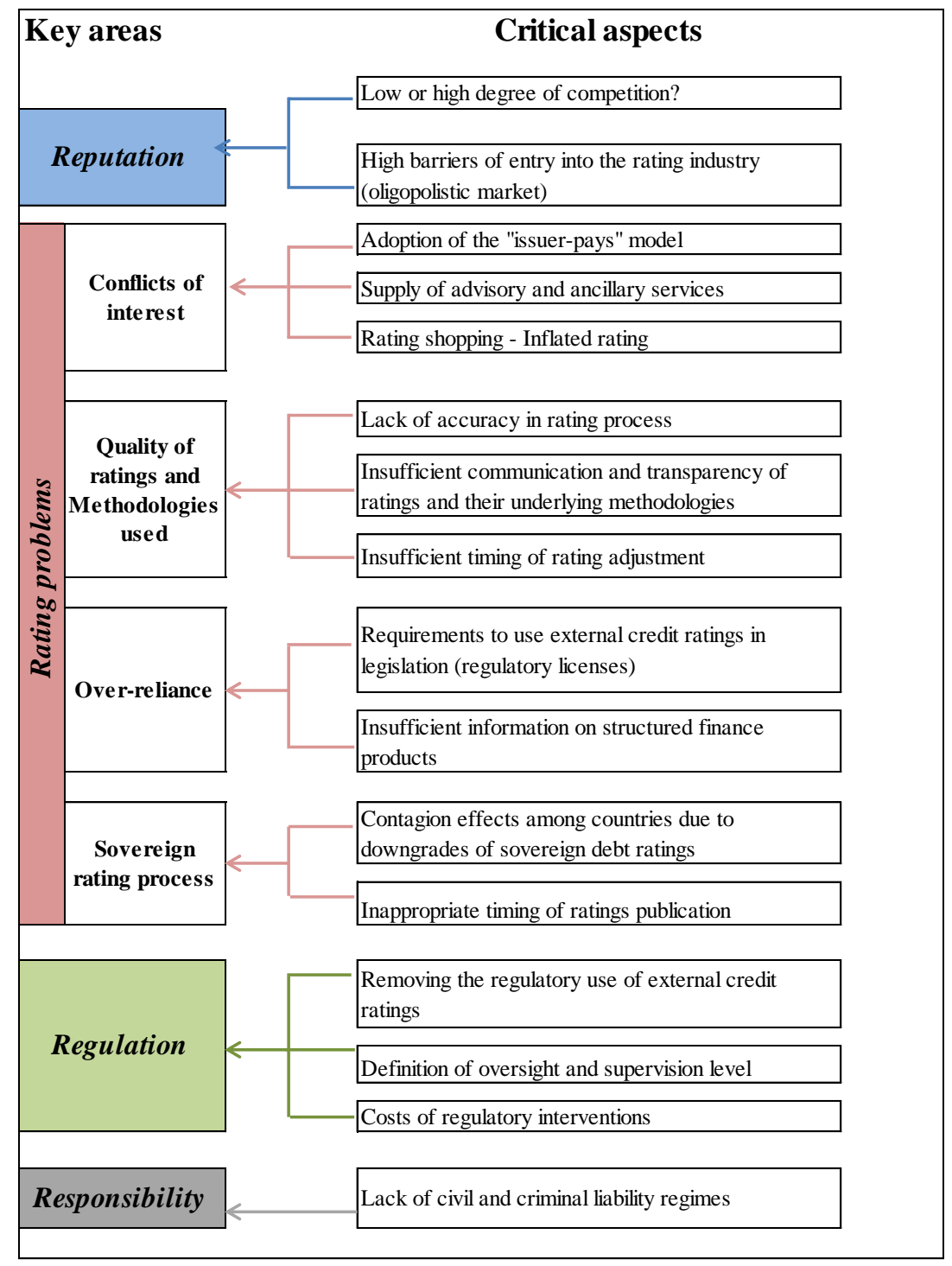

Figure 1. Key points of the literature review

\section{Regulatory Measures Introduced in the U.S.}

For a long time, CRAs enjoyed the largest uncontrolled power in the USA financial market; however, in the wake of the financial crisis, the United States (U.S.) Congress has gradually enacted a set of reforms, and rating agencies ceased to be unregulated entities. In September 
2006, the U.S. Congress approved the "Credit Rating Agency Reform Act (CRARA)", which introduced, in section 15E of the Securities Exchange Act of 1934, a number of rules with the declared purpose of improving the quality of ratings, eliminating conflicts of interest and promoting accountability, transparency and competition in the ratings market (SEC 2006). In particular, the CRARA regulates a recognition procedure for agencies wanting to operate as a Nationally Recognized Statistical Rating Organization (NRSRO). In the ensuing years, President Obama signed the "Dodd-Frank Wall Street Reform and Consumer Protection Act of 2010". The measures introduced in sections ranging from 931 to $939(\mathrm{H})$ of the Dodd-Frank Act are intended to strengthen and enhance the supervision and control over the activities of rating agencies. The law also provides the establishment, within the SEC, of the Office of Credit Ratings (Section 932(a)(8)), which is assigned the task of oversight compliance with federal securities laws and rules by the NRSROs and, in particular, of conducting an audit at least annually on each agency recorded. With the new rules increasing, particularly the disclosure requirements of the agencies to the SEC and market are also increasing; moreover, the reform requires NRSROs to change the structure of the board, of which half must be composed of independent directors to whom to entrust the task formulation of supervising the rating process and the effectiveness of internal controls. It is interesting to note that Section 939 is devoted, in part, to the provisions concerning the revision or elimination of the reliance on credit ratings for regulatory purposes, and Section 933 introduces a regime of civil liability as investors can sue CRAs for knowingly or recklessly failing to conduct a reasonable investigation of facts or for failing to obtain an analysis from an independent source (SEC 2010). In the last few years, the legislation relating to the activities of NRSROs has been integrated continuously. At the EU level, the financial scandals of important multinational companies led European regulators to focus on the role played by rating agencies in the financial system. The European Commission (EC), after noting the technical advice of the Committee of European Securities Regulators, concludes that no new legislative initiatives are needed for the time being because the EU legislative approach, such as the "Financial Services Action Plan Directives" and the self-regulation initiatives at the international level (Code of Conduct Fundamentals for Credit Rating Agencies - IOSCO Code), were a sufficiently robust framework for the rating sector (EC 2006). Nevertheless, given the events of the global economy experienced between 2007 and 2008, the first EU Regulation in November 2009 was enacted.

\section{Regulatory Framework of CRAs: The European Approach}

After the financial crisis, the EC has adopted a gradual approach to the regulation of the CRAs. The regulatory path can be ideally divided into three stages. The first was in response to the subprime crisis during which Regulation n. 1060/2009 was issued. The second phase is characterized by Regulation n. 513/2011, which follows the establishment of the European System of Financial Supervisors (ESFS), among which is the European Securities and Markets Authority (ESMA), to strengthen financial market oversight. The last is a consequence of the euro debt crisis during which a regulation and directive were issued (Regulation n. 462/2013 and Directive 2013/14/EU). 


\subsection{Regulation N. 1060/2009: The First Response to Financial Meltdown}

In the post-financial crisis phase, the EC has placed emphasis on regulation and supervision, focusing on both the rating of structured products and conflicts of interest associated with them. In this context, the purposes of Regulation n. 1060/2009 are to enhance the integrity, transparency, responsibility, governance and reliability of credit rating activities and to improve the quality of credit ratings, thus contributing to achieve a high level of investor protection (art.1). The new rules introduce a series of obligations and prohibitions for CRAs operating in the EU and provide the registration requirement for the agencies that issue credit ratings in the Community. Furthermore, Regulation n. 1060/2009 establishes that credit ratings can be used for regulatory purposes by credit institutions, investment firms and insurance companies only if they are issued by CRAs registered in accordance with the procedure delineated by such law (art. 4, paragraph 1). As several researchers have highlighted, the EU identifies four overall objectives targeting improving the process of credit rating issuance (Staikouras 2012). The Regulation of 2009 is also based on these purposes: 1) Avoidance or, at least, the management of conflicts of interest; 2) Improvement of methodologies and quality of rating; 3) Increasing of transparency by setting disclosure obligations for CRAs; and 4) Efficient registration and surveillance framework. The main innovative features are listed in Table 1.

Table 1. Main features of reform in response to the subprime crisis (Regulation n. 1060/2009)

\begin{tabular}{|c|c|c|}
\hline $\begin{array}{l}\text { CRA } \\
\text { Regulation }\end{array}$ & Main innovative features & Articles \\
\hline \multirow{13}{*}{$\begin{array}{l}\text { Regulation (EC) } \\
\text { N.1060/2009 }\end{array}$} & $\begin{array}{l}\text { Equivalence system for third countries agencies a ffiliated to the agencies registered in Members } \\
\text { States. }\end{array}$ & Art. 5 \\
\hline & Policies and procedures to manage and avoid conflicts of interest. & $\begin{array}{l}\text { Art. 6; Annex I, } \\
\text { Sec. A and B }\end{array}$ \\
\hline & F inancial analyst rotation system. & $\begin{array}{l}\text { Art.7, Annex I, } \\
\text { Sec. C }\end{array}$ \\
\hline & $\begin{array}{l}\text { Compensation and performance evaluation of rating analysts are not linked to the CRA's revenue } \\
\text { derived from rated entities. }\end{array}$ & Art. 7 \\
\hline & Rating analysts are not allowed to participate in fee negotiations & Art. 7 \\
\hline & Methodologies should be rigorous, systematic, updated and backed by historical data. & Art. 8 \\
\hline & $\begin{array}{l}\text { Transparency: to disclosure procedures and methodologies used in determining the rating; to } \\
\text { indicate different symbol for rating categories of structured finance instruments respect to financial } \\
\text { instruments or financial obligations; to disclose policies and procedures regarding unsolicited } \\
\text { credit ratings. }\end{array}$ & $\begin{array}{l}\text { Art. 10; Annex I, } \\
\text { Sec. D }\end{array}$ \\
\hline & $\begin{array}{l}\text { CESR must to keep central rep ository where all the in formation of ratings issued performan ces are } \\
\text { stored. }\end{array}$ & Art. 11 \\
\hline & Compulsory registration system throu gh CESR for agencies issu ing credit ratings in the EU. & Artt.14-20 \\
\hline & The CRAs' supervisory is entrusted to National Authorities. & Artt. $22-35$ \\
\hline & National authorities establish sanction measures. & Art. 36 \\
\hline & Incompatibility between advisory services and rating activity. & Annex I, Sec. B \\
\hline & $\begin{array}{l}\text { Corporate governance: at least } 1 / 3 \text {, but no less than two, of the members of the administrative or } \\
\text { supervisory board shall be independent members not involved in credit rating activities. }\end{array}$ & Annex I, Sec. A \\
\hline
\end{tabular}

According to several scholars and the European Commission, unresolved issues remain due to the 'issuer pays' business model. In particular, problems remain relating to the competition and the oligopolistic nature of the rating industry characterized by high barriers to entry in terms of reputation and high start-up costs; the definition of a civil liability regime for CRAs; the use of ratings for regulatory purposes; and the overreliance on credit ratings (Public consultation on 
CRAs 2010; Staikouras 2012).

\subsection{Regulation N. 513/2011 Amending Regulation N. 1060/2009}

In the second phase, following the establishment of the new European architecture of supervision, the EC has decided to amend Regulation n.1060/2009 to incorporate the skills of ESMA into the provisions of Regulations of 2009. Regulation n. 513/2011 focuses on ESMA and all the tasks previously assigned to Committee of European Securities Regulators (CESR) and national authorities (artt. 2-5), also abolishing the colleges of supervisors. ESMA has full powers in several areas, as Table 2 shows. Finally, the Authority could impose penalties on CRAs who intentionally or negligently violate the provisions of the rules (artt. 36bis -36quinquies). Even at this stage, focused mainly on the reorganization of responsibilities between authorities, the problems highlighted by the literature and EC remain unresolved.

Table 2. Regulation n. 513/2011 as a consequence of the ESFS establishment: main changes

\begin{tabular}{|c|c|c|}
\hline CRA Regulation & Main innovative changes & Revised articles \\
\hline \multirow{8}{*}{$\begin{array}{l}\text { Regulation (EU) } \\
\text { N.513/2011 }\end{array}$} & $\begin{array}{l}\text { ESMA assumes competences on credit rating agencies as well as matters related } \\
\text { to ratings issued by rating agencies established in third countries that operate in } \\
\text { the EU. }\end{array}$ & Artt. 2-5 \\
\hline & ESMA assumes general competence relating to the registration of CRAs. & Artt. $15-20$ \\
\hline & $\begin{array}{l}\text { Prohibition for ESMA to interfere with the content of credit rating or } \\
\text { methodologies }\end{array}$ & Art. 23 \\
\hline & ESMA assumes competences on-going supervision of registered CRAs. & Art. $21-24$ \\
\hline & $\begin{array}{l}\text { In order to carry out its duties, ESMA may request information, conduct all } \\
\text { necessary general investigations and on-site inspections. }\end{array}$ & $\begin{array}{l}\text { Artt. } 23 \text { ter, } 23 \text { quarter, } 23 \\
\text { quinquies }\end{array}$ \\
\hline & $\begin{array}{l}\text { Competent National Authorities are responsible for the supervision and } \\
\text { enforcement of Article } 4(1) \text { : the use of credit ratings. }\end{array}$ & Art. 25 bis \\
\hline & The colleges of competent authorities are deleted. & Artt. 28 and 29 (are deleted) \\
\hline & $\begin{array}{l}\text { ESMA may impose on a credit rating agency fines and periodic penalty } \\
\text { payments. }\end{array}$ & $\begin{array}{l}\text { Art. } 36 \text { bis, } 36 \text { ter, } 36 \\
\text { quater, } 36 \text { quinquies, } 36 \\
\text { sexies }\end{array}$ \\
\hline
\end{tabular}

5.3 The EU Response to the Euro Debt Crisis: Regulation N. 462/2013 and Directive 2013/14/EU

In the context of the euro meltdown, CRAs have been criticized for downgrading European sovereigns and thus exacerbating the difficult situations of countries such as Greece, Ireland, Portugal, and Spain (Arezki et al. 2011; Gartner et al. 2011). Therefore, in May 2013, the Commission issued Regulation n. 462/2013 of the European Parliament and of the Council, amending Regulation n. 1060/2009. As highlighted by the EC (EC 2013), the major changes introduced by the new regulatory package (Regulation n. 462/2013 and Directive 2013/14/EC) have the following objectives (see Table 3): 1) to reduce the overreliance on external credit ratings; 2) to improve the quality and transparency of credit ratings (especially for sovereign debt ratings); 3) to mitigate conflict of interest due to the "issuer pays model"; 4) to increase the limited competition in the credit rating market; 5) to create a European rating platform to publish all available ratings; and 6) to introduce a civil liability regime for CRAs. Regarding the first objective, the new provisions attempt to reduce overreliance on credit ratings by 
operators and investors both by imposing the establishment and use of internal assessments of risk arising from financial instruments and through the elimination of references to external ratings in legislation or in guidelines and rules proposed by the European Supervisory Authorities (Regulation n. 462/2013, art. 5 bis-quarter). In summary, Directive 2013/14/EC provides that competent authorities monitor the adequacy of the institutions' credit assessment processes and, where appropriate, encourage the reduction of reliance on credit ratings to conduct their investments in debt instruments. In relation to the second purpose, the new regulatory framework provides a set of rules to improve the quality of sovereign debt of EU Member States. According to article 8 bis, CRAs will establish a scheduling issue of sovereign ratings. Each agency is required to publish on its website and submit to the ESMA, on an annual basis, a calendar setting the dates for the publication of solicited sovereign ratings and a maximum of three dates for the publication of unsolicited sovereign ratings (Annex I, Sect. D, Part III). In addition, these ratings may be published only on Friday after the close of business or one hour before the opening of European markets. The objective of this calendaring system is to allow operators and investors to prepare for receiving news that could potentially adversely affect the stability of the market. With regard to the third purpose, Regulation $\mathrm{n}$. $462 / 2013$ has added rules to mitigate the risk of conflict of interest to enhance the perception of the independence of CRAs from the rated entities. For instance, the CRA is obliged to abstain from issuing credit ratings if a shareholder or a member holds at least $10 \%$ of the capital or voting rights of the CRA or holds $10 \%$ or more of a rated entity and if he/she is also a member of the administrative or supervisory board of the rated entity. Instead, the CRA must inform the public in the case where such percentage is at least equal to 5\% (art. 6a; Annex I, Sec. B). Furthermore, concerning structured finance instruments, the issuers of such financial products must engage at least two different CRAs for the credit rating issue (art. 8c). In addition, in compliance with article $6(\mathrm{~b})$, a mandatory rotation mechanism is also provided that requires issuers of structured products with underlying re-securitized assets to change the rating agency every 4 years. Concerning the use of multiple CRAs, to foster competition, the EU legislation encourages the use of ratings issued by smaller CRAs, with no more than $10 \%$ of the total market share, evaluated by the issuers as capable of rating the relevant issuance or entity (art. 8 quinquies). It is also interesting to note that, as referenced in article $11 \mathrm{a}$, the regulatory framework provides the publication of all ratings on a European rating platform that will be operational by June 2015. The establishment of this system strives to increase the visibility and facilitate the comparability of the ratings issued by agencies operating in accordance with the EU Regulation. In this regard, in January 2015, in the Official Journal, the EC published three Delegated Regulations supplementing Regulation n. 1060/2009. This new law establishes regulatory technical standards to implement key provisions of the legislative framework on CRAs. In particular, Commission Delegated Regulation (EU) 2015/1 establishes technical standards for the periodic reporting to ESMA on fees charged by CRAs to their clients. The Commission Delegated Regulation (EU) 2015/2 states provisions for the presentation of the information that CRAs make available to the ESMA by the European Rating Platform, and the last Delegated Regulation (n.2015/3) establishes the new disclosure requirements for issuers, originators and sponsors on structured finance instruments. Finally, as highlighted in 2011 by the EU Commission's report, a large portion of Member States, except for France, do not have 
specific CRAs' civil liability regime (EC 2011). Given this situation, the Commission decided to propose new provisions on CRA Regulation. In compliance with articles 35a, when a credit rating agency commits, intentionally or negligently, any of the infringements denoted in the EU Regulation, an investor or issuer may claim damages due to that violation. The EU legislators in Annex III specify the possible infringements; nevertheless, article 35(a) emphasizes that the burden of proof is on the issuer or the investor, who must present "accurate and detailed information" regarding the violation and prove the "impact" that the infringement committed had on the credit rating issued. Furthermore, the European legislators stated that terms such as "damage", "intention", "gross negligence", "reasonably relied", "due care", "impact", and "reasonable and proportionate limitations" are to be interpreted and applied in accordance with each national law. The main features are listed in Table 3.

Table 3. Regulatory changes regarding CRAs following the euro debt crisis

\begin{tabular}{|c|c|c|}
\hline $\begin{array}{l}\text { CRA Regulation and } \\
\text { Dir ective }\end{array}$ & Main innovative changes & Revised articles \\
\hline & Measures to reduce overreliance on credit rating. & $\begin{array}{l}\text { Art. } 5 \text { bis, } 5 \text { ter, } 5 \\
\text { quater }\end{array}$ \\
\hline \multirow{5}{*}{$\begin{array}{l}\text { Regulation (EU) } \\
\text { N.462/2013 }\end{array}$} & $\begin{array}{l}\text { CRA is required to publish (on an annual basis) a calendar setting the dates } \\
\text { for the publication of solicited and unsolicited sovereign ratings (maximum } \\
\text { three dates). }\end{array}$ & $\begin{array}{l}\text { Art. } 8 \text { bis; Annex I, } \\
\text { Sect. D, Part III }\end{array}$ \\
\hline & $\begin{array}{l}\text { Rules to enhance competition in the credit rating industry by using ratings } \\
\text { of smaller CRAs. }\end{array}$ & Art. 8 quinquies \\
\hline & $\begin{array}{l}\text { New measures to reduce conflicts of interest due to issuer-pays model: } \\
\text { CRAs' mandatory rotation mechanism; double credit rating of structured } \\
\text { finance instruments; to disclose publicly potential conflict of interest of } \\
\text { shareholders. }\end{array}$ & $\begin{array}{l}\text { Annex I, Sec.B; Art. } \\
6 \mathrm{a} ; 6 \mathrm{~b} ; \text { Art. } 8 \mathrm{c}\end{array}$ \\
\hline & $\begin{array}{l}\text { Civil liability regime for credit agencies in case they infringes CRA } \\
\text { regulation. }\end{array}$ & $\begin{array}{l}\text { Artt. 35a-36a; Annex } \\
\text { III }\end{array}$ \\
\hline & Publication of ratings on European Rating Platform. & Art. $11 \mathrm{a}$ \\
\hline $\begin{array}{l}\text { Directive 2013/14/EU amending } \\
\text { Directive 2003/41/EC, Directive } \\
\text { 2009/65/EC) and Directive } \\
2011 / 61 / E U\end{array}$ & $\begin{array}{l}\text { Reduce the risk that undertakings for collective investment in transferable } \\
\text { securities (UCITS), managers of alternative investment funds (AIFMs) and } \\
\text { institutions for occupational retirement provision (IORPs) make over- } \\
\text { reliance on credit ratings to carry out their investments in debt instruments. } \\
\text { The competent authorities monitor the adequacy of the institutions' credit } \\
\text { assessment processes and, where appropriate, they encourage the reduction } \\
\text { of reliance on credit ratings. }\end{array}$ & $\begin{array}{ll} & \\
\text { Art. } \quad 18, & \text { Directive } \\
2003 / 41 / \mathrm{CE} ; & \text { Art. } 51 \\
\text { Directive, } & \\
2009 / 65 / \mathrm{CE} ; & \\
\text { Art. } \quad 15 & \text { Directive } \\
2011 / 61 / \mathrm{UE} & \\
\end{array}$ \\
\hline
\end{tabular}

\section{Conclusion}

This section develops a critical discussion of European regulatory initiatives on rating agencies and proposes several conclusions. As explained above, CRAs operated as unregulated entities in the EU until 2009. The first Regulation was introduced in the wake of the financial turmoil, while in the United States, a legislative framework for the rating sector was previously in place. By comparing the Dodd-Frank Act with the two EU Regulations enacted between 2009 and 2011, issues such as overreliance, civil liability and quality of the rating process emerge yet remain unresolved (De Pascalis 2019 and 2015). Consequently, the developments of the euro debt crisis prompted legislators to issue a new full package of reforms to address outstanding weaknesses. With respect to the first key area, reputation, and the problems linked to the access of the European market rating, the first two regulations create a registration system that allows 
all CRAs that meet the organizational and professional requirements established in Annex II to operate in the EU (art. 15, Regulation n. 1060/2009). Considering the high degree of concentration of the rating sector, this procedure can be viewed as a first step towards the implementation of competition in the European rating market. With the last reform, European legislators introduce additional measures to promote the controlled entry of new competitors in the rating sector to gradually decrease the power of the three main CRAs. Specifically, Regulation n. 462/2013 encourages the use of smaller agencies that hold less than $10 \%$ of the market share (art. 8d); it creates a European Rating Platform (art. 11a). In the platform available on the ESMA website by December 2016, both the historical performance and the data on ratings issued by CRAs converge. This measure of advertising improves the transparency around credit ratings and could promote the implementation of competition because it helps to increase the reputational capital of the smaller agencies among investors and market stakeholders. Several researchers have claimed that the business model "issuer pays" and the relevance attributed from lawmakers to credit rating have distorted the competitive mechanisms in the rating market (Partnoy 2009; White 2018 and 2013). Nevertheless, the first two EU reforms not only offer a means to resolve the structural problems of the rating industry related to the business model and the oligopolistic nature of the rating sector, but they do not address the dependence of issuers on regulatory licenses. As previously emphasized, both Regulations n. 1060/2009 and n. 513/2011 are mainly focused on establishing a surveillance and monitoring system of CRAs' activities. In particular, regarding the area of rating problems, the adoption of the issuer pays model creates a long-standing business relationship between a CRA and the issuer to guarantee revenues or to secure additional work and profits. Consequently, CRAs that have the objective of increasing or maintaining their market share tend to release inflated and inaccurate ratings to please the rated entity, leading to over-reliance on data supplied by the issuer. Moreover, as shown in the literature, the application of this remuneration system encourages the phenomenon of ratings shopping (Sketa and Vedkamp 2009). Although several scholars proposed different solutions to replace such a model (Mathis et al. 2009; Pagano and Volpin 2010; Ponce 2012; Taibleson and Listokin 2010), European legislators, in the last regulation (462/2013), preferred to only incorporate a number of additional rules with respect to the original formulation (artts. 6-7 Regulation 1060/2009). These measures target strengthening the independence of the rating company and preventing and managing conflicts of interest. As identified in the EU Commission's studies, all remuneration models may involve conflict of interest; therefore, it does not require the use of a particular model by law (European Commission 2016 and 2011). With reference to overreliance, the use of ratings in regulation has generated considerable uncritical reliance by financial market participants regarding assessments of credit risk by CRAs. The importance accorded to credit ratings from a regulatory perspective (regulatory licenses) has contributed to enhancing the reputation and power of the three major rating agencies (Partnoy 2009). Recently, the EC has published a report concerning the assessment of potential alternative tools to external credit ratings (European Commission 2016). The available options considered by the EC are market-based measurement of credit risk, internal credit risk assessment tools and third-party assessments (Accounting-based measures, OECD Country Risk classification and Scorings by Central Banks). However, despite the variety of possibilities, the Commission 
established that there are no feasible alternatives to entirely replace external credit ratings (European Commission 2016:8). In addition, targeting a reduction in the reliance on credit ratings, the last reform includes a rule regarding the obligation to disclose to the public, on an ongoing basis, specific information concerning the underlying assets of structured finance products because this would favor the possibility for investors to conduct an independent assessment of such instruments (art. 8b, Regulation n. 462/2013). Given the events of the financial meltdown generated in the market for structured products, to preserve the transparency of the rating process and the quality of ratings, the European legislature has provided, in each regulation, rules regarding an ongoing review of the methodologies used and a supervision system by the ESMA. In addition, relative to the quality and methodologies used to assess sovereign ratings, as noted above, several researchers who focused on the analysis of euro debt crisis have reported a lack of transparency, objectivity and thoroughness in the sovereign ratings elaboration process in addition to an over-reliance with contagion effects among countries in the case of downgrades (Arezki et al. 2011; Gartner et al. 2011; Tahmoorespour et al. 2018). Consequently, in the last Regulation, the European lawmakers have promptly introduced several rules with the objective of ensuring the quality of sovereign debt ratings that will be issued in a manner that ensures the analysis of the individual specificity of each Member State. Moreover, a statement announcing the revision of a given group of countries will be prohibited if it is not accompanied by individual country reports (art. 8a). Furthermore, the Commission also evaluated the feasibility of establishing an EU creditworthiness assessment for sovereign debt concluding that a European agency does not appear to be an appropriate solution by considering the needs of investors and the objective of eliminating the over-reliance on external credit ratings in sovereign bonds markets (European Commission 2015). With reference to the critical issue, regulation, the real problem is the importance accorded to ratings from lawmakers in recent decades, for example, tying the rating to the amount of capital or securities that banks must hold to be considered safe. In this regard, our analysis of European reforms emphasizes that the intervention of the legislature was heavily delayed and not very incisive. The first two reforms established that, for regulatory purposes, financial institutions and European Supervisory Authorities could use only the ratings issued by registered CRAs. Nonetheless, one of the main objectives of Regulation $n$. $462 / 2013$ is to eliminate "in the presence of adequate alternatives", all references to ratings contained in the legislation by January 2020 (art. 5c). Another delicate and complex theme of Regulation n. 462/2013 is the regime of civil liability, such that several CRAs participated in the regulatory debate (European Commission 2010). The new law opens the way for the recognition of a civil liability of CRAs; however, the provisions introduced have critical problems. The first one observed concerns the burden of proof that is charged to investors and issuers. Furthermore, the reference to the national law of the Member States for the interpretation and implementation of the essential elements of the legislation on civil liability is another relevant problem (De Pascalis 2019 and 2015). Therefore, with the objective of assessing the practical consequences of the regulatory framework adopted by the EU, we must await the future development of the discipline, the work of the member countries and possible case law based on violations of European rules. In conclusion, we might note that the first EU regulation checked behavior rating agencies while avoiding excessive regulatory intervention 


\section{$\triangle 1$ Macrothink}

International Journal of Accounting and Financial Reporting

ISSN 2162-3082 2019, Vol. 9, No. 1

(Staikouras 2012). The last version of the EU Regulation appears to attempt to respond to most of the major critical issues identified by scholars. However, as noted, gray areas remain to be explored, which are also interesting future research lines, relating to an alternative to the business model adopted, the increasing competition in the rating sector, a decrease in the overreliance on external credit ratings and a mutual efficient regime of civil liability. However, the evolution of rules in the 2009-2013 period and the new directions in EU regulatory practice confirm the relevance and the interconnections between the concepts of the CRAs' role in financial markets and the ongoing regulation approach.

\section{Authors' Contributions}

This paper is the result of collaboration between the authors. In particular, Giusy Cavallaro contributed to sections 4, 5 and 6 and Annarita Trotta contributed to sections 1, 2 and 3.

\section{References}

Alsakka, R. et al. (2015). Market impact under a new regulatory regime: Credit rating agencies in Europe. Economic Notes, 44(2), 275-308.

Arezki, R. et al. (2011). Sovereign Rating News and Financial Markets Spillovers: Evidence from the European Debt Crisis. IMF Working Papers, 11(68), 1-27.

Basel Committee on Banking Supervision. (2010, December). Basel III: A global regulatory framework for more resilient banks and banking systems. Retrieved from http://www.bis.org/publ/bcbs189.pdf

Becker, B., \& Milbourn, T. (2011). How did increased competition affect credit ratings?. Journal of Financial Economics, 101, 493-514.

Bergevin, P. (2010). Addicted to Ratings: The Case for Reducing Governments Reliance on Credit Ratings. C.D. Howe Institute Backgrounder, 130, 1-8.

Cash, D. (2018). Regulation and the Credit Rating Agencies (1st ed.). New York: Routledge.

Cheng, M., \& Neamtiu, M. (2009). An Empirical Analysis of Changes in Credit Rating Properties: Timeliness, Accuracy and Volatility. Journal of Accounting and Economics, 47(1/2), 108-130.

Darbellay, A., \& Partnoy, F. (2012). Credit Rating Agencies and Regulatory Reform. San Diego Legal Studies Paper, 12(082), 1-30.

De Pascalis, F. (2015). Civil Liability of Credit Rating Agencies from a European Perspective: Development and Contents of Art 35(a) of Regulation (EU) No 462/2013. International and Comparative Corporate Law Journal, on Civil Liability of Credit Rating Agencies in the European Union - Selected Legal and Economic Aspects, 11(2), 1-20.

De Pascalis, F. (2019). Public Enforcement and the Civil Liability Regime in the European Regulation of Credit Rating Agencies (CRAs): the Quest for Interplay. In M. Andenas, \& O. Cherednychenko (Eds.), Financial Regulation and Civil Liability in European Law: Towards a More Coordinated Approach. Edward Elgar. 
De Vincentiis, P., \& Pia, P. (2017). Small is beautiful? A comparison of major and minor credit rating agencies credibility. International Journal of Business Administration, 8(1), 1-21.

Deb, P. et al. (2011). Whither the credit ratings industry?. Bank of England Financial Stability Paper No. 9, 1-23.

Deipenbrock, G. (2018). Direct Supervisory Powers of the European Securities and Markets Authority (ESMA) in the Realm of Credit Rating Agencies-Some Critical Observations in a Broader Context. European Business Law Review, 29(2), 169-203.

Deipenbrock, G., \& Andenas, M. T. (2016). Regulating and Supervising Credit Rating Agencies in the European Union. International and Comparative Corporate Law Journal 9(1), 1-17.

Dittrich, F. (2007). The Credit Rating Industry: Competition and Regulation. Morrisville: Lulu Press.

Ellis, N., S. et al. (2012). Is Imposing Liability on Credit Rating Agencies a Good Idea? Credit Rating Agency Reform in the Aftermath of the Global Financial Crisis. Stanford Journal of Law Business \& Finance, 17(2), 175-222.

European Commission. (2006, March 11). Communication from the Commission on Credit Rating Agencies 2006/C59/02. Retrieved from https://eur-lex.europa.eu/legal-content/IT/TXT/PDF/?uri=CELEX:52006XC0311(01)\&from= GA

European Commission. (2010, November 5). Public Consultation on Credit Rating Agencies. Retrieved from http://ec.europa.eu/finance/consultations/2010/cra/docs/cpaper_en.pdf

European Commission. (2011, November). Commission staff working paper, impact assessment, accompanying the document Proposal for a Regulation amending Regulation (EC) No 1060/ 2009 on credit rating agencies and a Proposal for a Directive. Retrieved from http://ec.europa.eu/internal_market/securities /docs/agencies/SEC_2011_1354_en.pdf

European Commission. (2013, June 18). New rules on credit rating agencies (CRAs) enter into force Memo/13/571. Retrieved from http://europa.eu/rapid/press-release_MEMO-13-571_en.htm

European Commission. (2015, December 1). Study on the feasibility of alternatives to credit ratings. $\quad$ Retrieved from https://ec.europa.eu/info/system/files/alternatives-to-credit-rating-study 01122015en.pdf

European Commission. (2016, October 18). Report from the Commission to the European Parliament and the Council on alternative tools to external credit ratings, the state of the credit rating market, competition and governance in the credit rating industry, the state of the structured finance instruments rating market and on the feasibility of a European Credit Rating Agency. Retrieved from http://eur-lex.europa.eu/legal-content/IT/TXT/PDF/?uri=CELEX:52016 DC0664\&from=EN 


\section{$\triangle 1$ Macrothink}

International Journal of Accounting and Financial Reporting

ISSN 2162-3082 2019, Vol. 9, No. 1

Financial Stability Forum. (2012, November 5). Roadmap and workshop for reducing reliance on CRA ratings, from http://www.fsb.org/wp-content/uploads/r_121105b.pdf

Gaillard, N., \& Waibel, M. (2018). The Icarus Syndrome: How Credit Rating Agencies Lost Their Quasi Immunity. SMU Law Review, 71(4), 1077-1091.

Gärtner M., et al. (2011). PIGS or Lambs? The European Sovereign Debt Crisis and the Role of Rating Agencies. International Advances in Economic Research, 17(3), 288-99.

Haar, B. (2013). Civil Liability of Credit Rating Agencies - Regulatory All-or-Nothing Approaches between Immunity and Over-Deterrence. University of Oslo Faculty of Law Research Paper, 2, 1-24.

Hill, C., A. (2004). Regulating the Rating Agencies. Washington University Law Review, 82, 43-94.

Hunt, J., P. (2009). Credit Rating Agencies and the "worldwide credit crisis": the limits of reputation, the insufficiency of reform, and a proposal for improvement. Columbia Business Law Review, 1, 1-74.

Husisian, G. (1990). What Standard of Care Should Apply to the World's Shortest Editorials? An Analysis of Bond Rating Agency Liability. Cornell Law Review, 75(2), 411-61.

Lagner, T., \& Zu Knyphausen-Aufse, D. (2012). Rating agencies as Gatekeepers to the Capital Market: pratical implication of 40 years of research. Financial Markets Institutions \& Instruments, 21, 157-202.

Maciariello, E. (2018). Rating Liability, Analysis of Article 33-bis of the Regulation (EC) 1060/2009. Banca Impresa Società, 1, 157-188.

Mariano, B. (2012). Market power and reputational concerns in the rating industry. Journal of Banking \& Finance, 36, 1615-26.

Mathis, J. et al. (2009). Rating the raters: Are reputation concerns powerful enough to discipline rating agencies?. Journal of Monetary Economics, 56(5), 657-74.

Möllers, T., M., J., \& Niedorf, C. (2014). Regulation and Liability of Credit Rating Agencies - A More Efficient European Law?. European Company \& Financial Law Review, 11(3), 333-63.

Moosa, I., A. (2017). The regulation of credit rating agencies: a realistic view. Journal of Banking Regulation, 18(2), 180-200.

Nästegard, E. (2015). Does Member State Law Make Article 35a of the EU Regulation on Credit Rating Agencies Redundant?. International and Comparative Corporate Law Journal 11(2), 1-20.

Pagano, M., \& Volpin, P. (2010). Credit Ratings Failures and Policy Options. Economic Policy, 42, 402-31. 
Partnoy, F. (1999). The Siskel and Ebert of financial markets? Two thumbs down for the credit rating agencies. Washington University Law Quarterly, 77(3), 619-715.

Partnoy, F. (2009). Overdependence on Credit Ratings Was a Primary Cause of the Crisis. San Diego Legal Studies Paper, 15, 1-19.

Picciau, C. (2018). The Evolution of the Liability of Credit Rating Agencies in the United States and in the European Union: Regulation after the Crisis. European Company and Financial Law Review, 15(2), 339-402.

Ponce, J. (2012). The Quality of Credit Ratings: A Two-Sided Market Perspective. Economic Systems, 36(2), 294-306.

Security and Exchange Commission. (2006, September 29). Credit Rating Agency Reform Act of $2006 . \quad$ Retrieved from http://www.sec.gov/divisions/marketreg/ratingagency/cra-reform-act-2006.pdf

Security and Exchange Commission. (2010, July 21). Dodd-Frank Wall Street Reform and Consumer Protection Act. Retrieved from https://www.sec.gov/answers/about-lawsshtml.html\#df2010

Skreta, V., \& Veldkamp, L. (2009). Ratings shopping and asset complexity: A theory of ratings inflation. Journal of Monetary Economics, 56(5), 678-95.

Staikouras, P. K. (2012). A Theoretical and Empirical Review of the EU Regulation on Credit Rating Agencies: In Search of Truth, Not Scapegoats. Financial Markets Institutions and Instrument, 21, 71-155.

Stolper, A. (2009). Regulation of credit rating agencies. Journal of Banking \& Finance, 33, 1266-73.

Sy, A. N. R. (2009). The Systemic Regulation of Credit Rating Agencies and Rated Markets. IMF Working Paper, WP/09/129, 1-33.

Tahmoorespour, R. et al. (2018). Sovereign Debt and Sovereign Credit Rating: Literature Review. Journal of Insurance and Financial Management, 4(1), 20-56.

Taibleson, B., \& Listokin, Y. (2010). If You Misrate, then You Lose: Improving Credit Rating Accuracy Through Incentive Compensation. Yale Law School, 203, 91-113.

Taupin, B. (2018). Justification and critique in the credit rating system. In I. Chambost, M. Lenglet \& Y. Tadjeddine (Eds.), The Making of Finance: Perspectives from the Social Sciences (pp. 208-215). Routledge.

Wang, L. (2018). The Civil Liability of Credit Rating in China. In Proceedings of the 2018 2nd International Conference on Management, Education and Social Science (Ed.), Advances in Social Science, Education and Humanities Research (pp.235-238). Atlantis Press.

White, L. J. (2010). The Credit Rating Agencies. Journal of Economic Perspectives, 24(2), 211-226. 


\section{Macrothink}

International Journal of Accounting and Financial Reporting ISSN 2162-3082 2019, Vol. 9, No. 1

White, L. J. (2013). Credit Rating Agencies: An Overview. Annual Review of Financial Economics, 5, 93-122.

White, L. J. (2018). The Credit Rating Agencies and Their Role in the Financial System. In E. Brousseau, (Ed.), Oxford Handbook on Institutions, International Economic Governance, and Market Regulation. Oxford University Press

Xia, H. (2014). Can investor-paid credit rating agencies improve the information quality of issuer-paid rating agencies. Journal of Financial Economics, 111(2), 450-468.

\section{Copyright Disclaimer}

Copyright for this article is retained by the author(s), with first publication rights granted to the journal.

This is an open-access article distributed under the terms and conditions of the Creative Commons Attribution license (http://creativecommons.org/licenses/by/4.0/) 